\title{
Gambaran Penerapan Prinsip Higiene Sanitasi Makanan di Kantin PT. Semen Indonesia (Persero) Tbk, Tuban, Jawa Timur
}

\section{The Description of Hygiene Sanitation Principles at the Canteen of PT. Semen Indonesia (Persero) Tbk, Tuban, East Java}

\author{
Grace Bella K Nussy*
}

\begin{abstract}
ABSTRAK
Latar Belakang: Pada usia yang produktif dan sanggup untuk bekerja memerlukan asupan makanan yang bergizi dan aman. Pentingnya penyediaan asupan gizi di lingkungan kerja, PT. Semen Indonesia (Persero) Tbk. Pabrik Tuban menyediakan layanan makanan dan fasilitas kantin bagi pekerja maupun pengunjung yang datang. Berdasarkan laporan tahunan BPOM tahun 2016 dan 2017, dilihat dari lokasi terjadinya KLB keracunan pangan terbesar ketiga terjadi di area kantor/ pabrik. Mencegah kejadian serupa salah satunya dengan menerapkan prinsip higiene sanitasi makanan pada kegiatan pengolahan makanan.

Tujuan: Tujuan dari penulisan artikel adalah untuk mengetahui dan mempelajari penerapan higiene sanitasi makanan mulai dari pemilihan bahan makanan sampai penyajian makanan yang telah dilaksanakan di kantin PT. Semen Indonesia (Persero) Tbk. Pabrik Tuban.

Metode: Jenis penelitian ini adalah penelitian deskriptif dengan menggunakan metode pendekatan kualitatif berupa observasi dan wawancara.

Hasil: Terdapat enam prinsip dalam penerapan higiene sanitasi makanan, yaitu 1) Pemilihan bahan makanan, 2) Penyimpanan bahan makanan, 3) Pengolahan makanan, 4) Penyimpanan makanan jadi/ masak, 5) Pengangkutan makanan dan 6) Penyajian makanan. Kegiatan pengolahan makanan di kantin PT. Semen Indonesia (Persero) Tbk Pabrik Tuban sebagian besar telah memenuhi dan melaksanakan prinsip higiene sanitasi makanan. Namun pada kegiatan penyimpanan bahan baku, pengolahan dan penyajian makanan masih ditemukan beberapa aspek yang belum memenuhi prinsip higiene sanitasi makanan. Kesimpulan: Kegiatan pengolahan makanan sebagian besar telah memenuhi dan beberapa aspek ada yang belum memenuhi yaitu penyimpanan bahan baku, pengolahan makanan dan penyajian makanan.
\end{abstract}

Kata Kunci: Higiene Sanitasi, Pengolahan Makanan, Kantin Pabrik

\section{ABSTRACT}

Background: At a productive age and able to work, we need nutritious and safe food intake. The importance of providing nutritional intake in the work environment, PT. Semen Indonesia (Persero) Tbk. The Tuban factory provides food services and canteen facilities for workers and visitors who come. Based on the BPOM annual report for 2016 and 2017, judging by the location of the outbreak, the third largest food poisoning occurred in the office / factory area. One of the ways to prevent similar incidents is by applying the principles of food sanitation hygiene in food processing activities.

Purpose: The purpose of this articles is to identify and study the application of food sanitation hygiene starting from the selection of food ingredients to serving food that has been implemented in the canteen of PT. Semen Indonesia (Persero) Tbk. Tuban factory.

Methods: This type of this research was a descriptive study using a qualitative approach in the form of observation and interviews.

Results: There were six principles in the application of food sanitation hygiene, namely 1) Selection of food ingredients, 2) Storage of food stuffs, 3) Food processing, 4) Storage of prepared / cooked food, 5) Food transportation and 6) Food presentation. Food processing at the canteen of PT. Semen Indonesia (Persero) Tbk Pabrik Tuban were mostly meeting the standard requirement for food hygiene and sanitation. However, in the cold storage section, food preparation still found few standards that was not met, such as storage of raw materials, food processing and food serving.

Conclusion: Most of the food processing activities have fulfilled and some have not especially the principles of food hygiene and sanitation towards raw materials in the cold storage.

Keywords: Food Hygiene and Sanitation, Food Processing, Canteen in Factory 


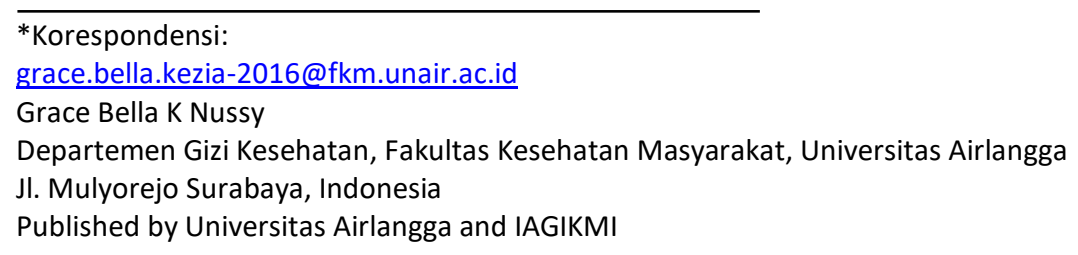

\section{PENDAHULUAN}

Makanan memiliki fungsi dan peran penting bagi kehidupan manusia. Makanan menjadi sumber energi untuk melakukan aktivitas sehari-hari. Makanan juga berperan dalam mekanisme pertahan tubuh, metabolisme tubuh dan memelihara proses pertumbuhan/ perkembangan tubuh ${ }^{1}$.

Pada usia dewasa yang telah sanggup bekerja, memerlukan asupan gizi yang tepat dan mendukung dalam melakukan pekerjaannya. Kondisi status gizi serta pemenuhan asupan zat gizi pada pekerja berpengaruh pada produktivitas kerja, kemampuan melakukan suatu pekerjaan dan tingkat kelelahan yang dialami ${ }^{2}$. Manfaat menyediakan makanan bagi pekerja diantaranya memperbaiki status gizi pekerja, meningkatkan kecepatan dan ketelitian dalam bekerja, menghindari waktu istirahat curian, mencegah kehilangan waktu kerja karena absensi sakit, dan memberikan keuntungan bagi perusahaan dalam efisiensi penggunaan biaya tertentu dan peningkatan produktivitas kerja ${ }^{3}$. Sehingga penting untuk menyediakan makanan yang bergizi dan aman bagi pekerja, mengingat tenaga kerja memiliki peran dan kontribusi besar dalam perkembangan dan kesuksesan suatu institusi.

PT. Semen Indonesia (Persero) Tbk merupakan tipe perusahaan holding yang kegiatan usahanya meliputi kegiatan produksi dan pendistribusian semen serta produk hilir semen. Perusahaan yang pabriknya terletak di Kabupaten Tuban ini, memiliki tenaga kerja sebanyak 839 orang sebagai tenaga induk dan kurang lebih 3.400 orang sebagai tenaga Outsourcing.

Sebagian besar tenaga Outsourcing bekerja langsung di lapangan dengan menghadapi tugas dan kondisi lingkungan seperti iklim, suhu dan kelembapan berbeda. Sama halnya dengan tenaga kerja induk yang juga mengeluarkan tenaga dan pemikiran dalam menjalankan tugasnya. Menyadari bahwa pemenuhan asupan gizi memiliki manfaat yang penting bagi kesehatan dan produktivitas pekerjanya, perusahaan menyediakan pelayanan makanan dan fasilitas seperti kantin bagi pekerja maupun pengunjung yang datang.

Kegiatan pengolahan makanan di kantin perusahaan mulai dari pemilihan bahan makanan hingga penyajian makanan dilakukan oleh pihak ketiga dibawah pengawasan Unit Operasional Human Capital. Kegiatan pengolahan makanan yang tidak tepat dan benar dapat membahayakan kesehatan dan keselamatan manusia akibat adanya kontaminasi silang atau tercemar oleh bahan biologis, kimia dan benda lainnya ${ }^{4}$.

Kejadian keracunan pangan dapat terjadi di lingkungan kerja yang menyebabkan terganggunya kondisi kesehatan seperti muntah, diare hingga kematian. Berdasarkan Laporan Tahunan Badan Pengawas Obat dan
Makanan tahun 2016 dan 2017, ditinjau dari lokasinya menunjukan bahwa KLB Keracunan Pangan paling besar ketiga terjadi di area Kantor/ Pabrik 5,6. Kasus KLB Keracunan Pangan tersebut paling banyak disebabkan oleh kontaminasi Mikroba (seperti Staphylococcus aureus dan Bacillus cereus) dan beberapa kasus disebabkan oleh bahan Kimia (seperti Histamin dan Tetrodoksin) ${ }^{5,6}$. Menurut Arisanti R. (2018) faktor terjadinya kasus keracunan pangan teradi karena pengolahan makanan yang tidak baik dan penyimpanan yang tidak sesuai ${ }^{7}$. Hal tersebut menunjukan bahwa penting untuk menerapkan higiene sanitasi makanan di kantin perusahaan dengan tujuan untuk mencegah timbulnya permasalahan kesehatan atau penyakit akibat makanan (foodborne disease), mencegah kerugian tertentu, serta mengurangi potensi kerusakan atau pemborosan makanan ${ }^{1}$.

Higiene adalah kegiatan mempraktikan atau menerapkan prinsip kebersihan. Menurut Kementerian Kesehatan RI (2004), higiene adalah kegiatan memelihara dan melindungi kebersihan subjek ${ }^{8}$. Kegiatan higiene meliputi keadaan, praktek pola hidup, kondisi tempat dan lainnya yang berkaitan dengan proses produksi/ pengolahan makanan ${ }^{9}$. Sedangkan sanitasi menurut Marriott et al. (2006) adalah kegiatan pengembangan/ pemeliharaan untuk menciptakan dan memelihara kondisi yang higienis dan sehat ${ }^{10}$. Sanitasi dapat diartikan sebagai usaha mencegah penyakit atau potensi bahaya lainnya yang terjadi selama pengolahan makanan, yang menitikberatkan kegiatannya pada usaha kesehatan lingkungan atau faktor lingkungan di sekitar manusia ${ }^{1}$.

Menurut Permenkes RI Nomor 1096 Tahun 2011 tentang Higiene Sanitasi Jasaboga, higiene sanitasi makanan adalah upaya untuk mengendalikan faktor risiko terjadinya kontaminasi pada makanan yang berasal dari bahan makanan, orang atau penjamah makanan, tempat pengolahan dan peralatan yang digunakan ${ }^{11}$. Sehingga penelitian ini dilakukan dengan tujuan untuk mengetahui dan mempelajari kegiatan penerapan higiene sanitasi pada pengolahan makanan di kantin PT. Semen Persero (Tbk) Pabrik Tuban, apakah telah memenuhi prinsip higiene sanitasi makanan mulai dari pemilihan bahan hingga penyajian makanan.

\section{METODE}

Penelitian ini termasuk dalam penelitian deskriptif. Metode penelitian menggunakan pendekatan kualitatif dengan metode observasi dan wawancara untuk mengumpulkan data serta informasi lainnya. Penelitian dilakukan dalam kurun waktu satu bulan dan dilaksanakan di PT. Semen Indonesia (Persero) Tbk yang 
beralamat di Desa Sumberarum, Kecamatan Kerek, Kabupaten Tuban, Jawa Timur.

Instrumen observasi disusun berdasarkan Peraturan Menteri Kesehatan Nomor 1096 Tahun 2011 tentang Higiene Sanitasi Jasaboga ${ }^{11}$. Selain melakukan observasi pada kegiatan pengolahan makanan, metode wawancara juga dilakukan untuk memperoleh informasi terkait penerapan prinsip higiene sanitasi makanan di kantin perusahaan.

\section{HASIL DAN PEMBAHASAN}

PT. Semen Indonesia (Persero) Tbk. pabrik Tuban menyediakan fasilitas kantin bagi pekerjanya, tersedia berbagai menu masakan yang penyelenggaraannya dilakukan oleh salah satu katering di Kabupaten Tuban. Katering tersebut telah bermitra dengan perusahaan sejak tahun 2008. Menu makanan yang disediakan di kantin perusahaan sangat bervariasi, dalam sehari terdapat 10 hingga 15 menu yang disajikan dan setiap sebulan sekali menu akan di susun ulang dengan menambahkan menu baru, mengurangi atau inovasi lainnya.

Berdasarkan hasil wawancara, kantin perusahaan melayani pekerja maupun pengunjung setiap hari dengan pekerja kantin yang terbagi menjadi 2 shift yakni shift pertama mulai bekerja pukul 05.00 - 16.00 Wib dan shift kedua mulai bekerja pukul 16.00 - 24.00 Wib. Namun jika perusahaan sedang dalam konidisi overhole maka pada shift kedua pekerja kantin akan melaksanakan tugas pukul 16.00 - $01.00 \mathrm{Wib}$.

Proses penyelenggaraan makanan dilakukan langsung di dapur kantin yang setiap harinya bisa melayani kurang lebih 150 porsi makanan. Pada proses pengolahan makanan penting untuk memperhatikan penerapan higiene sanitasi makanan. Hal ini bertujuan agar makanan yang diolah dan disajikan, terjamin kualitas dan keamanannya. Berdasarkan Permenkes RI No. 1096/Menkes/Per/VI/2011 tentang Higiene Sanitasi Jasaboga, terdapat enam prinsip higiene sanitasi makanan yaitu pemilihan bahan makanan, penyimpanan bahan makanan, pengolahan makanan, penyimpanan makanan matang, pengangkutan makanan dan penyajian makanan $^{11}$.

\section{Prinsip 1: Pemilihan bahan makanan}

Pemilihan bahan makanan memperhatikan kondisi fisik dan kualitas/ mutu bahan pangan. Kualitas bahan makanan yang baik memiliki ciri tidak rusak dan terbebas dari cemaran bahaya misalnya cemaran kimia yang berasal dari pestisida ${ }^{12}$. Kualitas bahan makanan dapat ditentukan dari aspek gizi, aspek pancaindera, aspek bisnis dan aspek kesehatan ${ }^{13}$. Pemilihan bahan makanan di kantin PT. Semen Indonesia pabrik Tuban telah memperhatikan kondisi dan kualitas bahan yang akan diolah. Pemilihan bahan makanan dilakukan dengan memperhatikan aspek pancaindera seperti melihat kondisi fisik, warna dan aroma serta aspek bisnis yakni kesesuaian dengan kriteria mutu yang berlaku.

Pengadaan bahan makanan dilakukan oleh pengawas dapur dibantu dengan karyawan kantin lainnya, kegiatan diawali dengan pengecekan bahan yang dibutuhkan selanjutnya dilakukan pemesanan. Bahan makanan dipesan dengan mencantumkan jumlah dan spesifikasi bahan seperti ukuran, bentuk, penampilan dan warna. Kantin akan memesan bahan makanan pada supplier yang dipercaya dan resmi yakni pada dua hari sebelum menu makanan akan dimasak. Pengambilan bahan baku dilakukan oleh pekerja kantin yakni tenaga driver menggunakan mobil box tertutup yang sebelumnya telah dibersihkan. Pada bahan makanan segar seperti daging, ikan/udang pengiriman menggunakan coldbox agar tidak rusak dengan menjaga suhu aman pada bahan makanan tersebut.

Pada kegiatan penerimaan bahan makanan dilakukan kembali pemeriksaan dan pengecekan untuk memastikan bahan yang diterima sesuai dengan pemesanan. Pemeriksaan pada bahan mentah (segar) misalnya melihat keadaan yang baik, segar dan tidak rusak atau berubah bentuk dan warna. Pada bahan makanan kering memperhatikan kondisi yang baik, tidak berubah warna dan tidak berjamur. Pada makanan olahan pabrik telah memperhatikan label dan merk, kondisi kemasan dan tanggal kadaluwarsa. Hal ini telah memenuhi prinsip pemilihan bahan makanan yang tercantum dalam Permenkes RI No. 1096/Menkes/Per/VI/2011.

Setelah bahan dikonfirmasi sesuai dengan pemesanan, langsung akan dilakukan pembayaran. Jika tidak sesuai dengan pemesanan baik kualitas maupun kuantitas maka pihak kantin akan meminta untuk diganti/ ditambah, menunda pembayaran atau berhenti bermitra dengan supplier tersebut.

\section{Prinsip 2: Penyimpanan Bahan Makanan}

Pembusukan makanan di pengaruhi oleh beberapa faktor diantaranya jenis bahan, suhu, kelembaban dan kekeringan, udara, dan cahaya. Sehingga diperlukan teknik/ cara yang benar dan tepat untuk menyimpan bahan makanan dengan tujuan agar memiliki shelf life yang lama, mencegah pembusukan atau kerusakan pada bahan makanan ${ }^{14}$. Terdapat beberapa bahan makanan yang dibersihkan sebelum disimpan, misalnya pada makanan segar seperti ikan akan dibersihkan dari sisik dan darahnya, lalu dicuci dan dibumbui selanjutnya disimpan di freezer.

Berdasarkan Permenkes RI Nomor 1096 Tahun 2011, kegiatan penyimpanan bahan makanan di kantin PT. Semen Indonesia pabrik Tuban dalam beberapa hal telah memenuhi prinsip higiene sanitasi makanan pada kegiatan penyimpanan bahan makanan ${ }^{11}$. Prinsip penyimpanan yang diterapkan di kantin PT. Semen Indonesia pabrik Tuban adalah prinsip FIFO (First In First Out) yakni bahan makanan yang pertama masuk dalam tempat penyimpanan akan digunakan pertama pada proses pengolahan makanan.

Penyimpanan bahan makanan telah sesuai dengan jenis bahan makanan dan suhunya, misalnya pada bahan makanan kering seperti beras dan tepung disimpan dengan suhu ruang $25^{\circ} \mathrm{C}$, bahan makanan segar seperti sayuran hijau disimpan pada penyimpanan sejuk dengan suhu $10^{\circ} \mathrm{C}$, pada bahan makanan basah seperti ikan dan 
daging disimpan pada penyimpanan dingin sekali (freezing) dengan suhu $<0^{\circ} \mathrm{C}$.

Tidak terdapat ruangan khusus untuk penyimpanan bahan makanan, kerena rata-rata menu yang disajikan per harinya berbeda sehingga bahan makanan yang disimpan langsung keesokan harinya digunakan dalam proses pengolahan tanpa ada penyimpanan stock yang lebih. Tempat penyimpanan kering menggunakan rak, serta tersedia kotak untuk masing-masing bahan makanan. Rak penyimpanan telah sesuai dengan prinsip penyimpanan bahan makanan yakni tidak menempel pada lantai minimal $15 \mathrm{~cm}$, tidak menempel dinding dan langit-langit dengan jarak masingmasing yakni $5 \mathrm{~cm}$, dan $60 \mathrm{~cm}$. Hal ini bertujuan agar bahan makanan yang disimpan tidak rusak atau tumbuh jamur akibat menempel pada dinding atau lantai yang lembab ${ }^{15}$

Hasil observasi pada penyimpanan ikan yang sebelumnya telah dipotong dan dibumbui, selanjutnya diletakan pada wadah terpisah. Namun wadah penyimpanan tidak dilengkapi penutup dan peletakan wadah yang saling menindih dengan wadah lainnya (Gambar 1). Pada penyimpanan makanan yang sanitasinya tidak baik memiliki peluang 14,250 kali terjadinya kontaminasi Escherichia coli ${ }^{16}$.

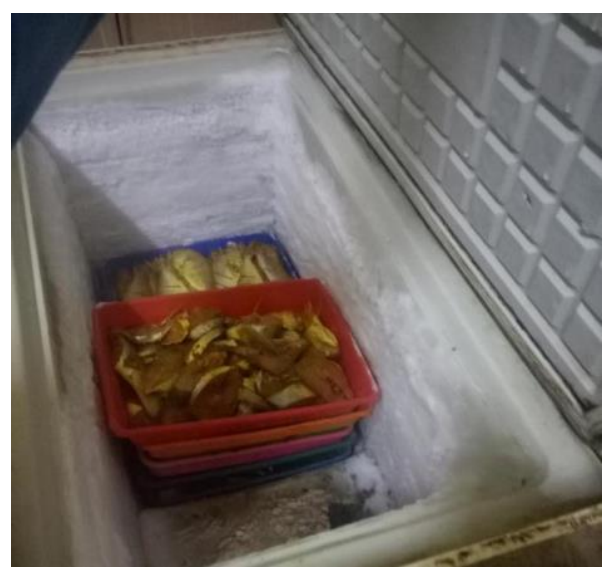

Gambar 1. Penyimpanan Ikan dalam Freezer

Kondisi kebersihan tempat penyimpanan selalu diperhatikan oleh pihak kantin. Setiap harinya sehabis kegiatan produksi, kotak penyimpanan bahan kering dan segar akan dibersihkan. Sedangkan untuk penyimpanan bahan makanan basah yakni freezer dibersihkan setiap seminggu sekali.

\section{Prinsip 3: Pengolahan makanan}

Pengolahan adalah suatu proses atau kegiatan mengubah bahan makanan dari mentah menjadi makanan siap santap dengan menambah bumbu, menggunakan metode tertentu, atau memberikan perlakuan khusus lainnya ${ }^{1}$. Berdasarkan hasil observasi, kegiatan pengolahan makanan beberapa aspek telah memenuhi prinsip higiene sanitasi yang tercantum dalam Permenkes RI Nomor 1096 Tahun 2011 tentang Higiene Sanitasi Jasaboga.

Tempat pengolahan makanan di kantin PT. Semen Indonesia (Persero) Tbk Pabrik Tuban memiliki kondisi bangunan yang kuat, aman, terpelihara dan bersih. Lantai tempat pengolahan makanan terbuat dari keramik yang kedap air, rata dan tidak retak/ licin. Lantai tempat pengolahan makanan memiliki luas $59 \mathrm{~m}^{2}$ dengan jumlah pekerja yang ada di area dapur sebanyak 7 orang. Sehingga luas ruang pengolahan makanan telah cukup untuk melakukan aktivitas bekerja dengan luas $2 \mathrm{~m}^{2}$ untuk pekerja dan luas $6,4 \mathrm{~m}^{2}$ perkiraan untuk keberadaan peralatan.

Langit-langit tempat pengolahan makanan menutupi area bangunan, permukaan rata, berwarna putih, mudah dibersihkan dan tidak menyerap air dengan jarak antara langit-langit dengan lantai 2,4 meter. Dinding berwarna putih, permukaan rata dan tidak lembab. Pencahayaan telah cukup untuk melakukan pekerjaan di area dapur. Pintu yang berhubungan dengan tempat pengolahan dapat menutup sendiri (self closing) dan dilengkapi dengan kassa untuk mencegah masuknya vektor seperti lalat.

Ventilasi yang berada di tempat pengolahan makanan memiliki luas yang cukup dan tersedia cookerhood, namun tidak terjadi sirkulasi udara yang baik sehingga ruangan pengolahan terasa panas (Gambar 2). Lingkungan kerja yang panas dapat menyebabkan gangguan perilaku dan performasi kerja seperti terjadinya kelelahan, pekerja akan sering mengambil istirahat curian, menurunnya produktivitas kerja, dan menyebabkan heat exhaustion ${ }^{17}$.

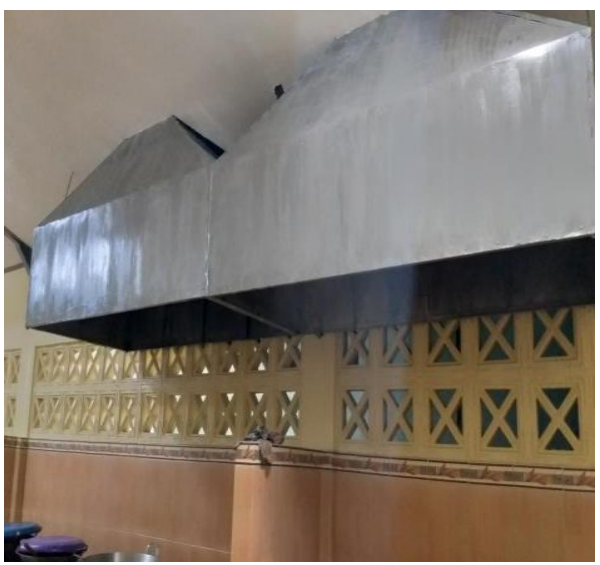

Gambar 2. Cookerhood dan ventilasi di ruang pengolahan makanan

Menu yang disusun telah memperhatikan prinsip pengolahan yang baik yakni ketersediaan bahan, jenis bahan, waktu dan proses pengolahan, serta keahlian tenaga memasak dalam mengolah makanan. Peralatan memasak yang digunakan kebanyakan berasal dari bahan stainless steel dan besi. Peralatan tersebut dinilai mudah dibersihkan dan aman karena tahan karat, tahan asam dan tidak mempengaruhi rasa atau warna dari masakan ${ }^{18}$. Kondisi peralatan tidak retak, baik dan bersih, masingmasing menu yang dimasak menggunakan perlatan yang terpisah.

Personal higiene penjamah makanan menjadi faktor dominan terjadinya kontaminasi Escherichia coli pada makanan yang diolah ${ }^{16}$. Hasil observasi dan wawancara menunjukan tidak semua tenaga yang bekerja 
di dapur mengenakan hairnet, sarung tangan, masker atau sepatu kedap air dengan alasan kondisi ruangan yang panas sehingga sering berkeringat dan membuat aktivitas bekerja menjadi tidak nyaman. Tidak lengkapnya mengenakan alat pelindung meningkatkan resiko terjadinya pencemaran baik fisik, biologi dan kimia yang mungkin terbawa oleh penjamah makanan ${ }^{12}$.

Kegiatan memasak dimulai setiap harinya pukul 05.00 Wib, dengan jumlah menu 13-15 menu/ harinya. Proses pengolahan menu pagi dan siang ini dimulai dari kegiatan persiapan bahan, bumbu dan memasak membutuhkan waktu 1,5 jam sampai 2 jam. Bumbu masakan telah dipersiapkan dua atau sehari sebelumnya, misalnya pada masakan soto akan menggunakan bumbu kuning terdiri dari bawang putih, bawang merah dan kunyit. Sehingga proses kegiatan memasak tidak membutuhkan waktu.

Pada salah satu menu yang disajikan yakni asamasam mayung menggunakan ikan mayung yang segar. Ikan sebelumnya telah disortir dengan melihat kondisi kesegaran, warna insang dan aroma yang tidak terlalu amis/busuk. Selanjutnya ikan dibersihkan dari sisiknya dan dicuci dengan air mengalir. Setelah mempersiapkan bumbu akan langsung dimasak dengan menumis bumbu dan mengolahnya menu asam-asam mayung dengan suhu $>70^{\circ} \mathrm{C}$ selama 20 menit. Setelah matang, makanan akan diletakan pada wadah penyajian yang bersih terbuat dari stainless steel dan memiliki penutup.

\section{Prinsip 4: Penyimpanan makanan jadi / rusak}

Menu makanan yang belum disajikan akan disimpan dalam wadah terpisah dilengkapi penutup atau tetap di wajan dengan menyalakan api kecil. Hal ini bertujuan untuk menjaga kualitas makanan dengan memperhatikan suhu dan mencegah titik rawan dari perkembangan bakteri patogen dan pembusuk ${ }^{1}$.

Hasil wawancara bersama pengelola kantin menjelaskan bahwa menu makan malam akan disiapkan oleh karyawan kantin yang bekerja pada shift kedua yakni pada pukul 16.00 - $24.00 \mathrm{Wib}$. Menu yang disediakan seperti nasi goreng, mie goreng, mie kuah, dan lainnya. Sehingga jarang untuk menyimpan masakan pada menu pagi atau siang untuk dihidangkan pada menu makan malam. Makanan yang telah rusak dan tidak bisa dikonsumsi akan dibuang dalam kantung plastik dan diletakan pada pembuangan sementara. Sedangkan makanan yang masih tersisa dan layak untuk konsumsi akan diberikan pada pekerja kantin atau karyawan perusahaan di pos jaga/satpam.

\section{Prinsip 5: Pengangkutan makanan}

Kegiatan pengangkutan makanan telah memenuhi persyaratan higiene sanitasi makanan. Pengangkutan makanan di kantin PT. Semen Indonesia (Persero) Tbk. pabrik Tuban tidak membutuhkan banyak alat bantu, karena letak ruangan pengolahan dengan tempat penyajian memiliki jarak yang dekat.

Sedangkan pada makanan yang dipesan untuk diantarkan ke area pabrik atau kantor pusat akan diantarkan menggunakan mobil box tertutup. Mobil akan dibersihkan oleh petugas sebelum mengangkut atau mengantarkan makanan ke tempat tujuan. Makanan yang dipesan akan diantarkan dalam wadah tertutup dan bersih. Pada pemesanan nasi tumpeng untuk acara tertentu di kantor pusat akan di antarkan dalam kondisi hangat dan ditutupi dengan plastik tranparan.

\section{Prinsip 6: Penyajian makanan}

Kegiatan penyajian makanan di kantin perusahaan sebagian telah memenuhi prinsip higiene sanitasi makanan. Penyajian makanan dilakukan sekitar pukul 07.00-09.00 Wib. Sebelum makanan dihidangkan di meja penyajian, penjamah makanan akan melakukan pemeriksaan kembali. Pemeriksaan dilakukan secara inderamawi seperti menilai rasa, tekstur dan penampilan hidangan.

Makanan matang telah disajikan pada wadah yang terpisah, wadah higienis, utuh, kuat, dan tidak rusak/ cacat. Pada jam makan pagi atau siang, wadah penyajian akan dibuka sementara jika sudah sepi pengunjung maka wadah penyajian akan ditutup kembali oleh tenaga kerja yang bertugas. Hasil observasi menunjukan bahwa terdapat beberapa wadah penyajian gorengan dan jajan yang tidak memiliki penutup (Gambar 3). Hal ini dapat menyebabkan kontaminasi silang dari vektor seperti lalat yang membawa mikroba seperti Escherichia coli dan Staphylococcus aureus ke pangan dan berisiko menyebabkan penyakit akibat makanan atau foodborne disease ${ }^{16,19}$.

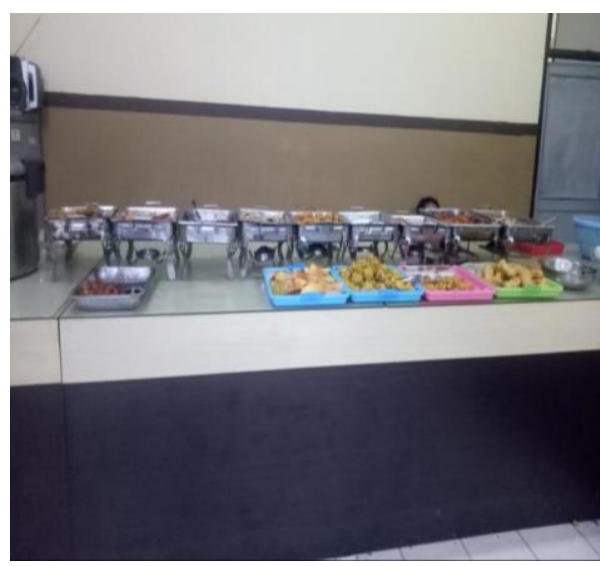

Gambar 3. Penyajian Makanan Matang

Pelayanan makanan di kantin Mahkota PT. Semen Indonesia (Persero) Tbk pabrik Tuban, termasuk dalam tipe self service atau prasmanan. Tipe prasmanan merupakan pelayanan makanan yang menghidangkan semua menu makanan di meja saji sesuai jenis menu atau berdasarkan urutan menu yang dihidangkan ${ }^{1}$. Konsumen atau pengunjung kantin akan mengambil menu yang diinginkan selanjutnya menuju meja kasir untuk melakukan pembayaran.

\section{KESIMPULAN}

Kegiatan pengolahan makanan di kantin PT. Semen Indonesia (Persero) Tbk Pabrik Tuban sebagian besar telah memenuhi dan melaksanakan prinsip higiene 
sanitasi makanan. Namun pada kegiatan penyimpanan bahan baku, pengolahan dan penyajian makanan masih ditemukan beberapa aspek yang belum memenuhi prinsip higiene sanitasi makanan.

Disarankan untuk menyediakan sarana yang mendukung untuk meningkatkan penerapan higene sanitasi seperti wadah terpisah dan dilengkapi dengan penutup, hal ini bertujuan untuk meminimalisir potensi kontaminasi silang yang terjadi. Menciptakan lingkungan pekerjaan yang nyaman dan aman bagi pekerja kantin dengan memperbaiki sistem penghawaan ruangan pengolahan makanan. Memberikan edukasi atau penyuluhan bagi tenaga kerja kantin terkait pentingnya penerapan higiene sanitasi makanan meliputi kegiatan pengolahan makanan dan mengenakan alat pelindung diri ketika bekerja, serta melakukan monitoring dan evaluasi berkala pada penerapan higiene sanitasi makanan pada kegiatan pengolahan makanan di kantin perusahaan.

\section{ACKNOWLEDGEMENT}

Peneliti mengucapkan terimakasih kepada PT. Semen Indonesia (Persero) Tbk Pabrik Tuban yang telah memberikan izin dan kesempatan bagi peneliti, berserta pembimbing magang instansi dan semua pihak sehingga penilitian ini dapat terlaksana.

\section{REFERENSI}

1. Wayansari, Lastmi; Anwar, Irfanny Z; Amri, Z. Bahan Ajar Gizi: Manajemen Sistem Penyelenggaraan Makanan Institusi. (Pusat Pendidikan Sumber Daya Manusia Kesehatan, 2018).

2. Tasmi, D., Lubis, H. sari \& Mahyuni, E. L. Hubungan Status Gizi dan Asupan Energi dengan Kelelahan Kerja pada Pekerja di PT. Perkebunan Nusantara I Pabrik Kelapa Sawit Pulau Tiga Tahun 2015. J. FKM USU 2015, 1-7 (2015).

3. Pritasari; Damayanti, Didit; Lestari, N. T. Bahan Ajar Gizi: Gizi Dalam Daur Kehidupan. (Pusat Pendidikan Sumber Daya Manusia Kesehatan, 2017).

4. Presiden Republik Indonesia. Undang Undang Republik Indonesia Nomor 18 Tahun 2012 Tentang Pangan. 1-58 (2012).

5. Indonesian National Agency of Drug and Food Control. Annual Report Indonesian National Agency of Drug and Food Control 2016. (2016).

6. BPOM. Laporan Tahunan Badan Pengawasan Obat dan Makanan tahun 2017. Badan Pengawas Obat dan Makanan (2017).

7. Arisanti, R. R., Indriani, C. \& Wilopo, S. A. Kontribusi agen dan faktor penyebab kejadian luar biasa keracunan pangan di Indonesia: kajian sistematis. Ber. Kedokt. Masy. 34, 99-106 (2018).

8. Kementerian Kesehatan Republik Indonesia. Keputusan Menteri Kesehatan Republik Indonesia Nomor 1204/Menkes/Sk/X/2004 Tentang Persyaratan Kesehatan Lingkungan Rumah Sakit. Menteri Kesehatan Republik Indonesia 1-61
(2004).

9. Surono, Ingrid S; Sudibyo, Agus; Waspodo, P. Pengantar Keamanan Pangan Untuk Industri Pangan. (DEEPUBLISH, 2016).

10. Marriott, Norman G; Gravani, R. B. Principles of Food Sanitation (Fifth Edition). (Springer Science+Business Media, Inc., 2006).

11. Kementerian Kesehatan Republik Indonesia. Peraturan Menteri Kesehatan Republik Indonesia Nomor 1096/Menkes/Per/Vi/2011 Tentang Higiene Sanitasi Jasaboga. Menteri Kesehatan Republik Indonesia 1-30 (2011).

12. Rahmadhani, D. \& Sumarmi, S. Gambaran Penerapan Prinsip Higiene Sanitasi Makanan Di PT Aerofood Indonesia, Tangerang, Banten. Amerta Nutr. 1, 291-299 (2017).

13. Christine. Pengawasan Mutu Dan Keamanan Pangan. Unsrat Press (UNSRAT PRESS, 2016).

14. Sari, D. A. . H. Teknologi dan Metode Penyimpanan Makanan sebagai Upaya Memperpanjang Shelf Life. Apl. Teknol. Pangan 2, 52-59 (2013).

15. Jiastuti, T. Higiene sanitasi pengelolaan makanan dan keberadaan bakteri pada makanan jadi di rsud dr harjono ponorogo. J. Kesehat. Lingkung. 10, 13-24 (2018).

16. Yunus, Salma P; Umboh, J.M.L; Pinontoan, O. Hubungan Personal Higiene dan Fasilitas Sanitasi dengan Kontaminasi Escherichia Coli Pada Makanan di Rumah Makan Padang Kota Manado dan Kota Bitung. J. Ilmu Kesehat. Masy. UNSRAT 5, 210-220 (2015).

17. Ramayanti, R. Analisis Hubungan Status Gizi Dan Iklim Kerja Dengan Kelelahan Kerja Di Catering Hikmah Food Surabaya. Indones. J. Occup. Saf. Heal. 4, 177-186 (2015).

18. Bakri, Bachyar; Intiyati, A. W. Bahan Ajar Gizi: Sistem Penyelenggaraan Makanan Institusi. (Pusat Pendidikan Sumber Daya Manusia Kesehatan, 2018).

19. Barreiro, C., Albano, H., Silva, J. \& Teixeira, P. Role of Flies as Vectors of Foodborne Pathogens in Rural Areas. ISRN Microbiol. 2013, 1-7 (2013). 